細

菌

の

脂

質

松 本亮・三輪匡男

静岡薬科大学生化学教室（静岡市小鹿 2-2-1）

\title{
Bacterial Lipids
}

Makoto Matsumoto and Masao Miwa

Department of Biochemistry, Shizuoka College of Pharmacy

(2-2-1 Oshika, Shizuoka-shi)

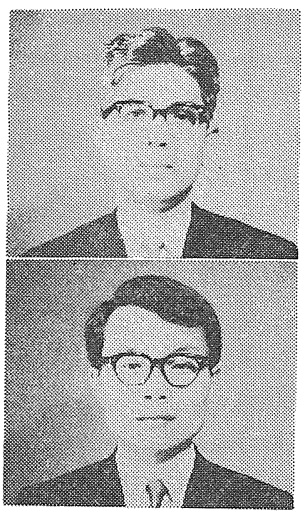

\section{1 は し がき}

細菌の脂質に関しては，すでに Kates ${ }^{1)}$ および Asselineau ら ${ }^{2)}$ の総説があるが，近年におおるこの分野の 研究成果についての総説は Kates および Wassef ら によりなされ，特に Ikawa ${ }^{4)}$ は菌体のリン脂質に関し， Shaw ${ }^{5)}$ は菌体のグリコリピドに関して詳しい総説を著 している。さらに，細菌に特有な複合脂質類の調製法や その脂質の性質については赤松(6)によりまとめられてい るので参照されたい。

細菌の脂質の大部分が膜に存在し ${ }^{4)}$, 複合脂質である リン脂質がその構成脂質の大部分を占めていると考えら れている。その組成は他の生物と比較した場合, ほとん どすべての菌体にステリン，スフィンゴリピドおよび高 級不飽和脂肪酸が含まれておらすす，中性糖脂質の含量も 少ないが，一方，遊離脂肪酸ならびに糖脂質の含量の高 いことが特徴的である。さらに構成脂肪酸としては, 分 枝 (iso-, anteiso-) 脂肪酸, シクロプロパン酸や水酸 基を持つオキシ脂肪酸が多く含まれている。

ここでは, 細菌脂質の主成分であるリン脂質および近 年研究の盛んな糖脂質の一種であるグリコシルジグリセ リド（glycosyl diglyceride）に主眼を拈き記述した。

\section{2 脂質の構造式}

$$
\begin{gathered}
\mathrm{H}_{2} \mathrm{C}-\mathrm{O}-\mathrm{COR} \\
\mathrm{ROCOC} \mathrm{H} \text { O } \\
\mathrm{H}_{2} \mathrm{C}-\mathrm{O}-\mathrm{P}-\mathrm{O}-\mathrm{CH}_{2}-\mathrm{CH}_{2}-\mathrm{NH}_{2} \\
\text { ○- } \\
\mathrm{O}^{-}
\end{gathered}
$$$$
\text { I ホスファチジルエタノールアミン }
$$

(Phosphatidylethanolamine)

$$
\begin{aligned}
& \mathrm{H}_{2} \mathrm{C}-\mathrm{O}-\mathrm{COR} \\
& \text { ROCOCH O } \\
& \mathrm{H}_{2} \mathrm{C}-\mathrm{O}-\stackrel{\mathrm{P}}{\mathrm{P}}-\mathrm{O}-\mathrm{CH}_{2} \mathrm{CH}_{2}-\stackrel{+}{\mathrm{N}}-\left(\mathrm{CH}_{3}\right)_{3} \\
& \text { O- } \\
& \mathrm{O}^{-}
\end{aligned}
$$

\footnotetext{
II

$$
\text { ホスフォチジルコリン }
$$
}$$
\text { (Phosphatidylcholine) }
$$

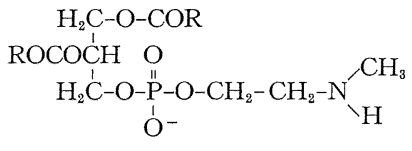

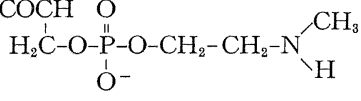

III N-メチルホスファチジルエタノールアミン

(N-methyl phosphatidylethanolamine)

$$
\begin{aligned}
& \mathrm{H}_{2} \mathrm{C}-\mathrm{O}-\mathrm{COR} \\
& \text { ROCOCH O } \\
& \text { IV }
\end{aligned}
$$

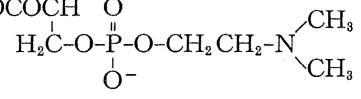

$\mathrm{N}, \mathrm{N}$-ジメチルホスファチジルエタノールアミン

(N,N-dimethyl phosphatidylethanolamine)

$$
\begin{aligned}
& \begin{array}{l}
\mathrm{H}_{2} \mathrm{C}-\mathrm{O}-\mathrm{COR} \\
\text { ROCOCH } \mathrm{O}
\end{array}
\end{aligned}
$$

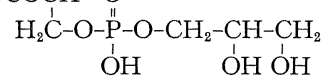

V

$$
\text { ホスファチジルグリセリン }
$$

(Phosphatidylglycerol)

$$
\begin{aligned}
& \mathrm{ROCOCH}_{2} \quad \stackrel{\mathrm{OH}}{\mathrm{H}} \mathrm{C}-\mathrm{O}-\mathrm{P}-\mathrm{O}-\mathrm{CH}_{2} \\
& \mathrm{ROCOCH} \mathrm{O} \mathrm{HCOH} \stackrel{\mathrm{O}}{\mathrm{HC}-\mathrm{O}-\mathrm{COR}}
\end{aligned}
$$

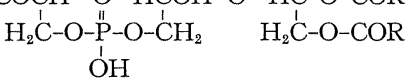

(ジホスフォチジルグリセリン)

(Cardiolipin, Diphosphatidylglycerol)

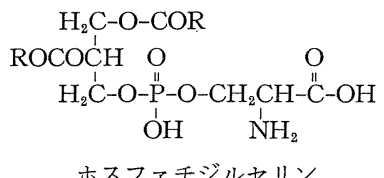

(Phosphatidylserine)

$$
\begin{gathered}
\mathrm{H}_{2} \mathrm{C}-\mathrm{O}-\mathrm{COR} \\
\text { ROCOCCH O } \\
\mathrm{H}_{2} \mathrm{C}-\mathrm{O}-\stackrel{\mathrm{P}}{\mathrm{P}}-\mathrm{OH} \\
\text { ÓH } \\
\text { OH }
\end{gathered}
$$

VIII

ホスファチジン酸

(Phosphatidic acid) 


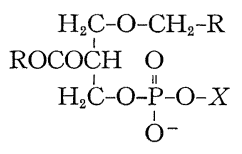

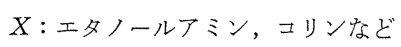

IX-a アルキルエーテル型リン脂質

(Alkylether type phospholipid)

$\mathrm{CH}_{2} \mathrm{OH}$

$\stackrel{\mathrm{C}}{\mathrm{HOH}}$

$\mathrm{CH}_{2}-\mathrm{O}$

$\mathrm{H}_{2} \mathrm{C}-\mathrm{O}^{-} \mathrm{CH}-\mathrm{CH}_{2} \mathrm{R}$

$\mathrm{ROCOCH} \mathrm{O}$

$\mathrm{H}_{2} \stackrel{\mathrm{C}}{\mathrm{C}} \mathrm{O}-\stackrel{\|}{\mathrm{P}}-\mathrm{O}-\mathrm{CH}_{2} \mathrm{CH}_{2}-\stackrel{+}{\mathrm{N}} \mathrm{H}_{3}$

$$
\mathrm{O}^{-}
$$

XI Clostridium butyricum

新アルデヒド生産性リン脂質

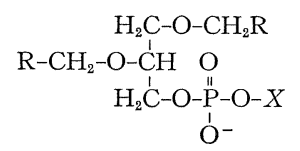

$X:$ グリセリン，グリセロホスフォイ

ト，ホスホリルグリセリン

IX-b ジェーテル型リン脂質

(Diether type phospholipid)

$$
\begin{gathered}
\mathrm{H}_{2} \mathrm{C}-\mathrm{O}-\mathrm{CH}=\mathrm{CH}-\mathrm{R} \\
\mathrm{ROCOC} \mathrm{H} \quad \mathrm{O} \\
\mathrm{H}_{2} \mathrm{C}-\mathrm{O}-\stackrel{\mathrm{P}}{\mathrm{P}}-\mathrm{O}-\mathrm{X} \\
\mathrm{O}^{-}
\end{gathered}
$$

$X:$ エタールアミン, コリンなど

$\mathrm{X}$ アルケニルエーテル型リン脂質

(Alkenylether type phospholipid)

(プラスマロゲソ plasmalogen)

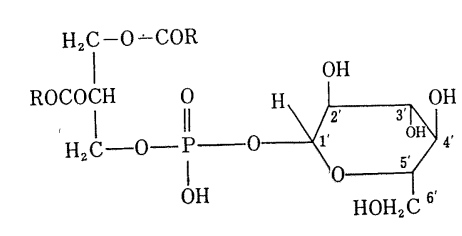

XIV ホスフォチジルグルコース

\section{$\mathrm{O}$}

$\mathrm{CH}_{2}-\mathrm{O}-\mathrm{COR} \quad \mathrm{H}_{2} \mathrm{C}-\mathrm{O}-\mathrm{C}-\mathrm{C}-\mathrm{CH}-\mathrm{R}$ ROCOCH O HCH ${ }_{1}^{\prime}$ H

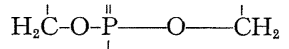
XII

アミノアシルホスファチジルグリセリン

(Aminoacyl phosphatidyl glycerol)

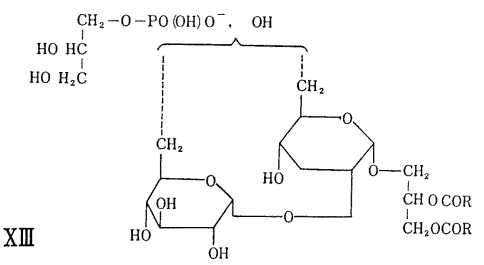

グリセリルホスホリルジグルコシルジグリセリド

(Glycerylphosphoryl diglucosyl diglyceride)

(Phosphatidyl glucose)

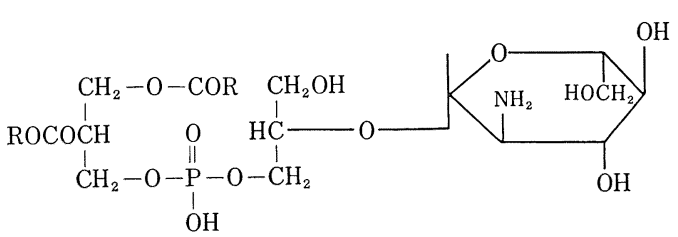

XVI１'-(1,2-ジアシル-sn-グリセロ-3-ホスホリル)-2'-O(2-アミノ-2-デオキシーD-グルコピラノシル)-sn-グ リセリン<smiles>CCCCCCCCC(N)C(O)CO</smiles>

XVIII スフィンゴシン (Sphigosine)

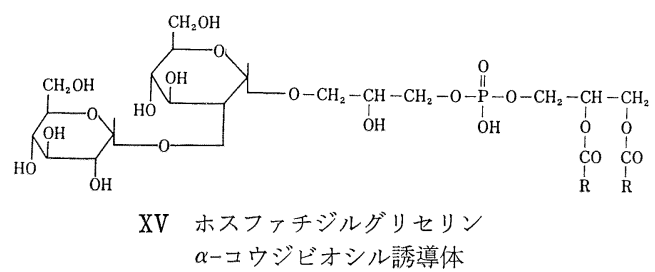

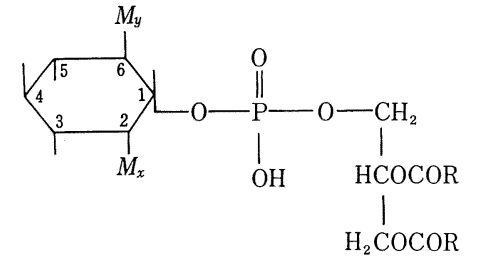

XVII マンノホスホイノシチド (Mannophosphoinositide)

\begin{tabular}{l|c:c}
\hline \multirow{2}{*}{$\begin{array}{c}\text { Manno- } \\
\text { side }\end{array}$} & \multicolumn{2}{|c}{$\begin{array}{c}\text { Manno- } \\
\text { pyranosyl }\end{array}$} \\
\cline { 2 - 3 } & $M_{x}$ & $M_{y}$ \\
\hline Mono & 1 & 0 \\
Di & 1 & 1 \\
Tri & 1 & 2 \\
Tetra & 1 & 3 \\
Penta & 1 & 4 \\
\hline
\end{tabular}

XIX-a：セラミドホスホリルエタノ (Ceramidophosphorylethanolamine)

$$
\begin{array}{ccc}
\mathrm{H}_{3} \mathrm{C}-\mathrm{CH}-\left(\mathrm{CH}_{2}\right)_{13}-\mathrm{CH}-\mathrm{CH}-\mathrm{O}-\stackrel{\text { P }}{\mathrm{C}}-\mathrm{O}-\mathrm{X} \\
\stackrel{\mathrm{I}}{\mathrm{C}} \mathrm{H}_{3} & \stackrel{\mathrm{O}}{\mathrm{N}} \mathrm{H} & \text { OH } \\
& \mathrm{R}^{\prime}-\stackrel{\mathrm{C}}{\mathrm{C}}=\mathrm{O} &
\end{array}
$$

$$
\begin{gathered}
X: \text { エタノールアミン, グリセリン } \\
\text { グリセロホスフェイト }
\end{gathered}
$$

(Ethanolamine, glycerol, glycerophosphate) XIX-a, b, c

$$
\begin{gathered}
\text {-b : セミミドホスホリルグリセ } \\
\text { リソ } \\
\text { (Ceramidophosphoryl- } \\
\text { glycerol) }
\end{gathered}
$$

-c：セラミドホスホリルグリセ ロホスフェイト

(Ceramidophosphorylglycerophosphate)

$$
\begin{aligned}
& \mathrm{CH}_{3}-\mathrm{CH}-\left(\mathrm{CH}_{2}\right)_{13}-\mathrm{CH}-\mathrm{CH}-\mathrm{CH}_{2}
\end{aligned}
$$

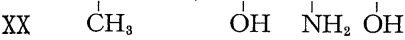

17-メチルオクタデカスフィンガニン

(17-Methyloctadecasphinganine)

$$
\begin{aligned}
& \mathrm{CH}_{8}-\left(\mathrm{CH}_{2}\right)_{12}-\mathrm{CH}=\mathrm{CH}-\mathrm{CH}-\mathrm{CH}-\mathrm{CH}_{2}-\mathrm{O}-\stackrel{\mathrm{O}}{\mathrm{P}}-\mathrm{O}-\mathrm{CH}_{2}-\mathrm{CH}_{2}-\stackrel{+}{\mathrm{N}}\left(\mathrm{CH}_{3}\right)_{3} \\
& \text { '́H } \mathrm{N}^{\prime} \mathrm{O} \mathrm{O}^{-} \\
& \mathrm{R}^{\prime}-\mathrm{CO}
\end{aligned}
$$$$
\text { XXI スフィンゴミェリン (Sphingomyelin) }
$$

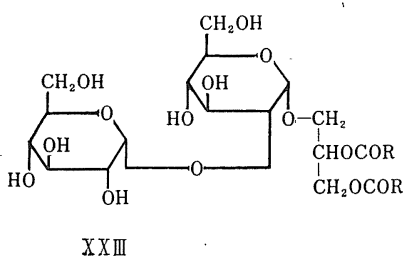

XXIII

$\leftarrow \alpha$-ガラクトシル-1 $\rightarrow 2-\alpha-$ グリ

コシルージグリセリド

( $\alpha$-galactosyl-1 $\rightarrow 2-\alpha$-glucosyldiglyceride)

$\alpha$-ジグルコシルジグリセリド $\rightarrow$ ( $\alpha$-Diglucosyl-diglyceride)

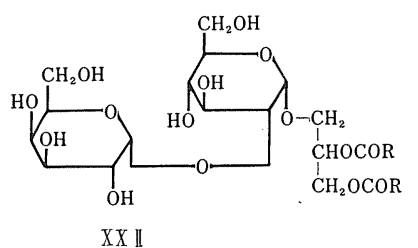




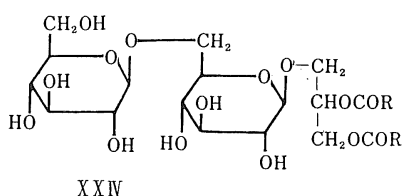

ß-ジグルコシルージグリセリド

( $\beta$-Diglucosyl-diglyceride)

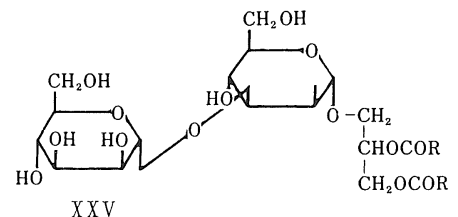

$\alpha$-ジマンノシルージグリセリド ( $\alpha$-Dimannosyl-diglyceride)

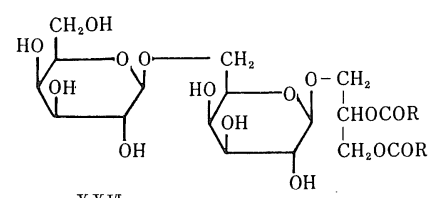

$X X V I$

$\beta$-ジガラクトシルージクリセリド

( $\beta$-Digalactosyl-diglyceride)

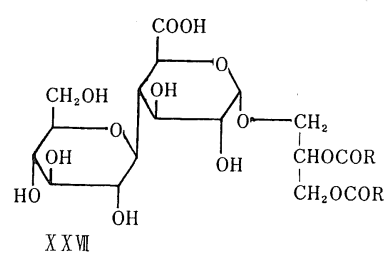

グルコシルーグルクロノシルー ジグリセリド

(Glucosyl-glucuronosyl-diglyceride)

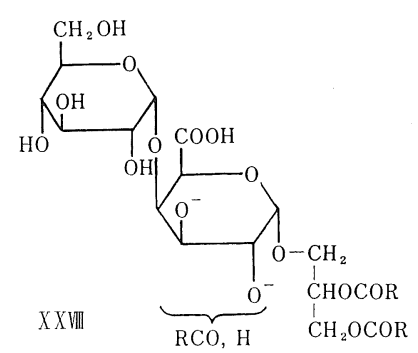

グルコシルーアシルーガラク ツロノシルジグリセリド

(Glucosyl-acylgalacturonosyl-diglyceride)

性の真性細菌の一般的な 構成 リン脂質で, Pseudomonadales 目と Eubacteriales 目 （真性細菌目）のグラム陰性 Azotobacteraceae, Rhizohiaceae, Achromobacteraceae, Enterobacteriaceae, Brucellaceae, Neisseriaceae などの科嘱するものに存在する ことが知られているい)。ホスファチジルエタ ノールアミンは, グラム陽性菌よりグラム陰 性菌に多く含まれている7)。グラム陽性菌の 内で endospore を生成する菌 (Bacillus cereus $^{8,, 9)}$, B.megaterium $^{10), 11)}$, Clostridium butyricum $^{12)}$ にはホスファチジルエタノー

\section{3 リン 脂 質}

先に述べたように, リン脂質は菌体の構成脂質の大部 分を占め, とくにグラム陰性菌では抽出可能な脂質の 80〜 90\%を，グラム陽性菌では 40〜 70\%を占めてい $る^{6)}$ 。

細菌のリン脂質の構成成分として, 動植物に一般的に 含まれているホスファチジルエタノールアミン（phosphatidylethanolamine，Ｉ）およびホスファチジルコリ ン (phosphatidylcholine, II) について比較してみる と, 前者のホスファチジルエタノールアミンはグラム陰 性菌の主成分であるが，グラム陽性菌においては，その 含量は低いか，あるいはほとんど含まれていない゙。一 方, 後者のホスファチジルコリンは Pseudomonadales 目およびRhizobiaceae 科の両者を除き他のほとんどす べての菌体に含まれていない。動物にまれにしかみられ ず，植物中に多く存在するホスファチジルグリセリン (phosphatidylglycerol, V) はグラム陽性菌のおもなり ン脂質の一つである。最近, Randle, Albro, Dittmer ら゙)はグラム陰性菌のリン脂質を検討した結果, グラム 陰性菌をそのリン脂質組成により四つのグループに分類 している。一方, 細菌のこれらリン脂質組成は, 菌の生 育状態および培養条件などにより多少変動することが知 られている。

\section{3・1 グリセロリン脂質}

3・1・1 ホスファチジルエタノールアミン (phosphatidylethanolamine, I )

この脂質は植物より動物に多く存在し, またグラム陰
ルアミンが含まれ，他のグラム陽性菌と異なっている。 Micrococcus halodenitrificans ${ }^{13)}, M$, cerificans $^{14)}$, Mycobacteriaceae 科のうち, M. avium, M. tuberculosis ${ }^{15)}$, さらに, この科に近縁の Nocardia brasilien$s i s^{16)}, N$. coeliaca ${ }^{17)}$ にも存在することが報告されてい るが，一般的に Lactobacillaceae, Micrococcaceae, Corynebacteriaceae, Mycobacteriaceae などの科には ほとんど存在しないか，または少量存在するのみで(4), 発生学上密接な関係にあるこれら菌体はリン脂質組成の 上でも共通点を持ち, 興味をひかれる。

3・1.2 ホスファチジルコリン (phosphatidylcholine III)

ホスファチジルコリンは, Pseudomonadales 目 [Rhodopseudomonas spheroides (chromatophores) ${ }^{18)}$, Rhodosprillum rubrum ${ }^{19)}$, Thiobacillus thiooxidans $\left.{ }^{20)}\right]$ とAgrobacterium 種 ${ }^{21)}{ }^{22)}$ を除き,大部分の菌体には存 在しないといわれていたが,最近, Brucella abortus ${ }^{23)}$, Hyphomicrobium vulgare ${ }^{24)}$, Nocardia coeliaca ${ }^{17)}$ の 主構成リン脂質であることが報告された。このことは, Actinomycetales 目としては初めてである。

3・1.3 ホスファチジルエタノールアミンの N-メチ ル誘導体 (N-methyl-, N, N-dimethyl phosphatidylethanolamine, III, IV)

Agrobacterium 種 $^{21), 22)}$, Hyphomicrobium vulgare $^{24)}$, Micrococcus cerificans ${ }^{14)}$, Proteus vulgaris ${ }^{21)}$, P. mirabilis ${ }^{25)}$, Clostridium butyricum ${ }^{12), 21), 26)}$ の脂 質画分に $\mathrm{N}$-メチル (III) および $\mathrm{N}, \mathrm{N}$-ジメチルホス ファチジルエタノールアミン (IV) がみいだされ, $H y$ - 
phomicrobium vulgare においては, N, N-ジメチルホ スファチジルエタノールアミンが全リン脂質の 36\%を 占める主構成リン脂質である ${ }^{24)}$ 。 た Ferrobacillus ferrooxidans $^{27)}$ のおもなリン脂質として $\mathrm{N}$-メチルホ スファチジルエタノールアミンが含まれ，この菌のリン 脂質組成はイオウ菌の組成と似ている。Randle ら ${ }^{7}$ は先 に述べたように Eubacteriales 目, Pseudomonadales 目のグラム陰性菌を，そのリン脂質組成から四つのグル ープに分類しており，この N-メチルホスファチジルエ タノールアミンを含む菌を 1 グループとしている。 Agrobacterium 種および Hyphomicrobium 種には先 に述べたように，ホスファチジルコリンが含まれている が，Proteus vulgaris およびClostridium butyricum にはこのリン脂質は存在せず，また生合成も行なわれて いないといわれている ${ }^{21}$ 。菌体においても N-メチルホ スファチジルエタノールアミンはラット肝におけると同 様, S-アデノシルメチオニンを利用し段階的なメチル化 により生合成されることが証明されている ${ }^{14)}$ 。

3・1.4 ホスファチジルグリセリン $(\mathrm{V})$ およびカルジ オリピンまたはジホスファチジルグリセリン (VI)

ホスファチジルグリセリン (V)はカルジオリピン (VI) とともに微生物リン脂質のおもなもので，とくにグラム 陽性菌に多く存在する。一般に菌体の構成脂質は培養条 件などによりかなり影響を受けるが，ホスファチジルグ リセリンは培地の $\mathrm{pH}$ 低下により減少し, そのアミノ 酸エステルが増加することが知られている。

菌体におけるホスファチジルグリセリンの生合成経路 は次のようなものである。

CDP-ジグリセリド+グリセリン-3-ホスフェイト

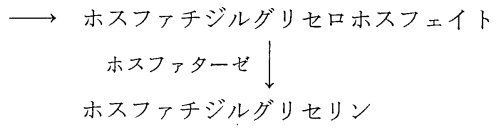

White と Tucker ら ${ }^{28}$ は, Haemophilus parainfuenzae におけるこのリン脂質の代謝を検討し，アシ ル化されているグリセリン部分より, リン酸やアシル基 を結合していないグリセリン部分の方が代謝回転が速 く, また, この菌体の他の主要構成リン脂質であるホス ファチジルエタノールアミンでも同様にエタノールアミ ンやリン酸部分がジグリセリド部分よりかなり速く代謝 されることを報告した。E. coli でも，また，ホスファ チジルグリセリンが主要構成リン脂質であるが，グリセ リン部分を標識したホスファチジルグリセリンを培地に 加え培養すると，これが E. coli の成長細胞に取り込ま れ，この放射能の一部がジホスファチジルグリセリンや ホスファチジルエタノールアミンのグリセリン部分に取 り込まれ，この脂質の一部が他の脂質へ交換されるとい われる ${ }^{29)}$ 。た，Mycoplasma mycoides におけるこれ
ら脂質の代謝回転を検討した結果からも，ホスファチジ ルグリセリンはジホスファチジルグリセリンの前駆体で あることが示されている301。カルジオリピンの構造とし て通常 4 分子の脂肪酸がエステル結合していることが知 られているが(VI), Streptococcus faecalis ATCC $9790^{31}$ から 5 分子の脂肪酸が結合したジホスファチジル グリセリンが分離された。Bacillus cereus より得たホ スホリパーゼCを用いてこの脂質を加水分解し，その水 解産物を分析した結果，この脂質はジホスファチジルグ リセリンのモノアシル誘導体（5 分子の脂肪酸を含む） であることが証明された。

3・1.5 ホスファチジルセリン（phosphatidylserine, VII）およびホスファチジン酸 (phosphatidic acid, VIII)

ホスファチジルセリンおよびホスファチジン酸は菌体 の構成リン脂質としてはごく少量存在するのみである が，ホスファチジルセリンはホスファチジルエタノール アミン生合成の中間体として知られており ${ }^{1)}$ ，またホス ファチジン酸は，グリセリドおよびグリセロリン脂質の 重要な中間体であることからすべての細菌に存在する可 能性がある。

$3 \cdot 1 \cdot 6$ エーテル結合を持つグリセロリン脂質

エーテル結合を持つグリセロリン脂質が動物組織に広 く存在し, そのエーテル結合の型により, アルキルエー テル型 $(\mathrm{IX}-\mathrm{a}, \mathrm{b})$ ，アルケニルエーテル型（プラスマロ ゲン, plasmalogen，X) の二つに分類される。

菌体にみられるエーテル型リン脂質をこの二つの型に 分けて見ると, アルキルエーテル型の脂質としては，高 濃度好塩菌であるHalobacterium cutirubrum ${ }^{32), 33)}, H$. halobium $^{34)}$ から分離されたホスファチジルグリセロホ スフェイト,カルジオリピン,ホスファチジルグリセリン の大部分がジェーテル結合 (IX-b) を持つことが Kates らにより報告されている。

酸加水分解によりアルデヒドを生成するアルケニルエ 一テル型脂質は Clostridium butyricum ${ }^{12)}$ から得られ たホスファチジルエタノールアミンの $55 \%$, N-モノメ チルホスファチジルエタノールアミンの $78 \%$ ， ホスフ アチジルグリセリンの $9 \%$ がこの種のリン脂質であるこ とが知られている。Kamio ら ${ }^{105)}$ はこのアルデヒド含有 リン脂質（プラスマロゲン）の分布を検討し，この種の リン脂質が偏性嫌気性菌, ならびに propionibacterium 属の一部の菌に特異的に存在し, 好気性菌および通性嫌 気性菌には認められず，また，これら菌を偏性嫌気的条 件下で培養してもこれら菌体中にはこの種のリン脂質は まったく認められないと報告している。

最近,われわれの研究室で ${ }^{35)}$, Clostridium butyricum のエタノールアミンリン脂質として，1 分子のグリセリ ン残基がプラスマロゲンにアセタールように結合した新 
しい型のリン脂質（XI）を見いだしている。

\section{$3 \cdot 2$ 細菌に特有なリン脂質}

3・2・1 ホスファチジルグリセリンのアミノアシルエ ステル (amino acyl phosphatidylglycerol, XII)

いく種かの菌にホスファチジルグリセリンのアミノア シルエステルが存在することを Macfarlane (1962) ${ }^{36)}$ が初めて報告し，アミノ酸としてリシンを初めアラニ ン，オルニチン，ロイシンなどがみいだされている。

リシルホスファチジルグリセリン (lysyl phosphatidyl glycerol, XII)

Bacillus cereus $^{37) ~ 39)}$, B. subtilis, B. megaterium, B. licheniformis $^{40)}$, Staphylococcus aureus ${ }^{36,411}$, Streptococcus faecalis (ATCC 9790) ${ }^{31}$ および乳酸 菌年) に見いだされ,その構造は1'-ホスファチジルー3'-OLーリシルーグリセリン (XII) であることが報告され ${ }^{37) ~ 399, ~}$ S. aureus では全リン脂質の約 $60 \%$ を占める主構成リ ン脂質である ${ }^{36), 41)}$ 。

さらに, Streptococcus faecalis ${ }^{31)}$ には上記 $3^{\prime}$ リシ ルェステルのほかに 2'-リシルエステル，2' $2^{\prime}, 3^{\prime}$-ジリシ ルエステルおよびアルギニルエステルも存在するようで ある。

オルニチニルホスファチジルグリセリン（ornithinyl phosphatidylglycerol)

Bacillus cereus $^{3), 43)}$, B. natto ${ }^{44)}$ 扝よび Thiobacillus thiooxidans $^{45}$ に見いだされ,この構造も先に述べたりシ ルエステルと類似の構造であることが報告されている

アラニルホスファチジルグリセリン (alanyl phosphatidyl glycerol)

Streptococcus faecalis (ATCC 9790) ${ }^{31}$, St. faecalis $10 \mathrm{C} 1^{46)}$, Butyrivibrio fibrisolvens D-1 株 ${ }^{47}$ 打よび Bacillus cereus $^{37), 48)}$ に存在し, St. faecalis $10 \mathrm{C} 1$ で はこのリン脂質が全リン脂質の $86 \%$ を占めている。

この他のアミノ酸を含むホスファチジルグリセリン関 連脂質

ロイシンおよびイソロイシンを含むホスファチジルグ リセリン誘導体が Butyrivibrio fibrisolvens D-1 株 ${ }^{47}$ に見いだされている。

これらアミノアシルリン脂質の生合成に関し，ホスフ アチジルグリセリンとアミノアシル-t-RNA が反応し アミノアシルホスファチジルグリセリン生成を触媒する トランスフェラーゼが Staphylococcus aureus ${ }^{49}$ 扩よ び Clostridium welchii ${ }^{50)}$ に見いだされ，それぞれリ シルホスファチジルグリセリンおよびアラニルホスファ チジルグリセリンを生成する。このトランスフェラーゼ は個々のアミノアシル-t-RNA に対して特異性が著し く高いことが示されている。さらに，Staphylococcus aureus $^{51)}$, Streptococcus faecalis ${ }^{37)}$ および Bacillus subtilis ${ }^{40)}$ では, リシルホスファチジルグリセリンの生
成は $\mathrm{pH}$ に依存することが示され，增殖期後半に おい て培地が酸性になるとこのリシルエステルが増加し, ホ スファチジルグリセリン含量が低くなる。 $\mathrm{pH}$ が中性近 辺に保たれた場合にはリシルエステルの生成は少量であ る。

同様に, グラム陽性菌で培養条件, 特に培地の $\mathrm{pH} の$ 変化により菌体のリン脂質含量が変わることが報告され

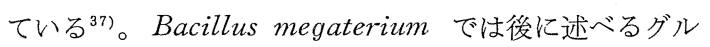
コサミニルホスファチジルグリセリンの含量が酸性培地 で増加し ${ }^{52)}$, Mycobacterium 607 $7^{53)}$ では $\mathrm{pH} 5.6$ の培 地でオルニチニルホスファチジルグリセリンが蓄積され るが，中性培地ではこのアミノアシルエステルははとん ど存在しないことが報告され，ここに示したように大部 分の菌体の脂質組成は菌の培養条件により著しく左右さ れることが知られている。

$3 \cdot 2 \cdot 2$ ホスホグリコリピド (phosphoglycolipid，グ ルコース含有リン脂質)

近年, 糖を含むりン脂質が菌体に存在することが報告 されており, Smith と Henrikson ら ${ }^{54), 55)}$ は, Mycoplasma laidlanii B 株からグルコースを含むリン脂質 を分離し,その分析結果として,リン: 糖 : グリセリン: 脂肪酸の比が $1: 1: 1: 2$ であることから,この脂質の構 造はホスファチジルグルコース（ホスファチジルー6'-グ ルコース）であることを報告し，また，この脂質が UDPグルコースとホスファチジン酸から合成されることを示 している ${ }^{56)}$ 。これに対し最近, この脂質の構造は, 通常の グリセロリン脂質の基本構造を持つものではなくてグリ セリルホスホリルジグルコシルジグリセリド（glyceryl phosphoryl diglucosyl diglyceride, XIII) であると報告 されている57)。た, Fischer ら ${ }^{58}$ により, Streptococcus lactis からグルコース:グリセリン: 脂肪酸：リン $(2: 2: 3: 1)$ のモル比で, ここに示した構造に似た 1-

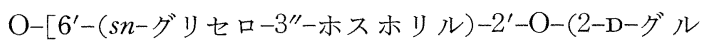

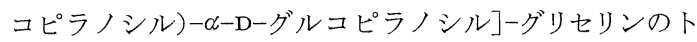
リーO-アシル誘導体が報告され，この脂質が S. lactis の 主要構成リン脂質であると報告している。初めに報告さ れたホスファチジルグルコース (phosphatidyl glucose) の構造を持つリン脂質が，Staphylococcus aureus にご く少量ではあるが存在し ${ }^{59)}$, その構造はホスファチジルー 1'ーグルコース（XIV）で代謝的には不活発であることが 報告された。

このほか，糖を含むリン脂質としてジグルコシルホス ファチジルグリセリンの構造を持つ脂質がStreptococcus faecalis $^{31,60), 61)}$, St. lactis ${ }^{60)}$, St. haemolyticus ${ }^{62)}$ に みいだされ，この脂質はアルカリ水解によりジグルコシ

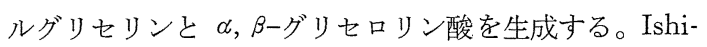
zuka, Yamakawa ${ }^{62)}$ は, St. haemolyticus D-58 株 から得られた脂質はホスファチジルー-1'グリセリンの $\alpha-$ 
コウジビオシルー $(1 \rightarrow 1)$ 誘導体 $(X V)$ の構造であ ることを明らかにした。これは後に述べるBacillus megaterium $^{64)}$ および Pseudomonas ovalis ${ }^{65}$ に 存在するグルコサミニルホスファチジルグリセリン の構造に似ている。Pseudomonas diminuta ${ }^{63}$ に 新ホスホグリコリピド，グルコシルジグリセリドを 含むホスファチジル誘導体（分析值；リン：グルコ ース：グリセリン:脂肪酸, $1: 1: 2: 4)$ が存在す ることが報告されているが，その詳しい構造は明ら かにされていない。

$3 \cdot 2 \cdot 3$ グルコサミニルホスファチジルグリセリン (glucosaminyl phosphatidyl glycerol XVI) ホスファチジルグリセリン誘導体として先に述べたア ミノアシル誘導体のほかに，グルコサミンを含む脂質が Bacillus megaterium ${ }^{64), 66), 67) ~ お よ ひ ゙ ~ P s e u d o m o n a s ~}$ ovalis $^{65}$ にみいだされ，その構造を Op den Kamp ら ${ }^{64)}$

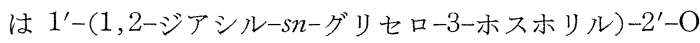

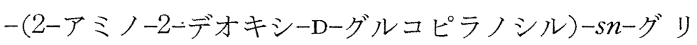
セリン $(\mathrm{XVI})$ であると報告している。構造式 (XVI) に

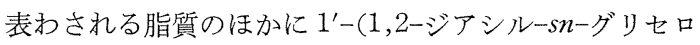
-3ーホスホリル)-3'-O- $\beta$-(2-アミノ-2-デオキシーDーグル コピラノシル)-sn-グリセリンが Bacillus megaterium に存在し ${ }^{68)}$, この両者ともにホスホリパーゼ $\mathrm{A}_{2}$ で水解 されるが, ホスホリパーゼ D により，3'-グルコサミニ ドのみが水解され， $2^{\prime}$ ーグルコサミニドは水解されず, また，ホスホリパーゼCによっては両者はいずれも水解 されなかった。この Bacillus megaterium のグルコサ ミニルホスファチジルグリセリン含量は, 先に述べたよ うに培養条件（培地 $\mathrm{pH}$ ) に依存し, $\mathrm{pH} 7.2$ で生育し た菌にはホスファチジルグリセリン含量は高いが, 酸性 $\mathrm{pH}$ のもとではグルコサミニルホスファチジルグリセリ ンが増加しホスファチジルグリセリンが減少する ${ }^{52), 66) 。 ~}$ 3・2・4 マンノホスホイノシチド

(mannophosphoinositide)

マンノースを含むホスファチジルイノシット誘導体 が, Mycobacteriaceae 科 ${ }^{69173)}$, Corynebacteriaceae 科 ${ }^{74}$ 76) で見いだされ，その構造は 1-ホスファチジルー

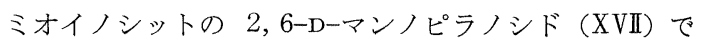
あることが Ballou ら ${ }^{697,77)}$ により明らかにされた。マン ノースを 1〜5 分子結合したものが知られているが，こ の内ジマンノシド $(x=1, y=1)$ が最も多く含まれてい る ${ }^{78)}$ 。類似した構造を持つイノシチドが Propionicbacterium shermanii にも少量存在するようである。 また，M. phlei にはトリアシル化されたジマンノホス ホイノシチド(0)が,ささにテトラアシル化されたジマン ノホスホイノシチド71)が M. phlei および Corynebacterium xerosis ${ }^{76)}$ にみいだされている。野島ら ${ }^{79}$ は， グルコースを含むホスホイノシチド誘導体が Mycobacte-
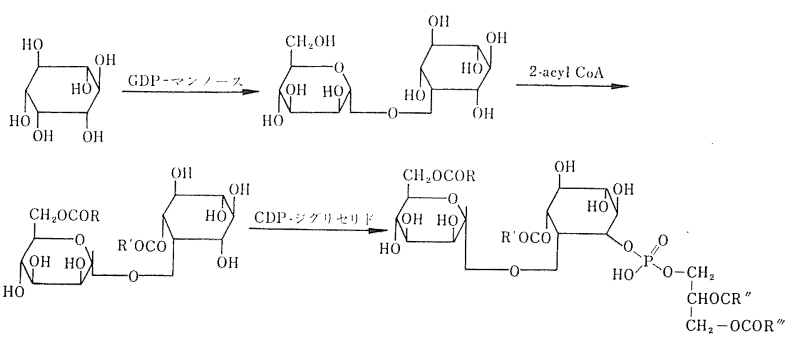

図-1 ジアシルホスフォチジルミオイノシットマンノシドの生合成経路 rium tuberculosis に存在することを示した。また， Mycobacteria 近縁の Nocardia coeliaca および $N$. polychromogenes にホスファチジルイノシットが存在 し，全リン脂質の $11 〜 14 \%$ を占めるといわれている ${ }^{17)}$ 。 Propionic acid bacteria に存在するアシル化されたホ スファチジルミオイノシットモノマンノシドの生合成経 路として, Shaw および Dinglinger ら ${ }^{80)}$ が同し propionic acid bacteria からジアシルイノシットモノマン ノシドを分離したことから，かれらは同じ菌に見いださ れるジアシルホスファチジルミオイノシットマンノシド の生合成経路として図-1 に示す反応を推定している ${ }^{80)}$ 。

\section{$3 \cdot 3$ 細菌スフィンゴリピド}

一般に，菌体にはスフィンゴリピド（分子内に長鎖塩 基：スフィンゴシン，XVIII を含む複合脂質）はまれに しか存在しないといわれ，動植物の脂質組成と比較し菌 体脂質の著しい特徴の一つである。最近, 嫌気性菌であ る Bacteroides melaninogenicus ${ }^{81), 82)}$ では, 構成リン 脂質の 50 70\% がホスホスフィンゴリピドでセラミド ホスホリルエタノールアミン (ceramido phosphoryl ethanolamine, XIX-a), セラミドホスホリルグリセリン (ceramido phosphoryl glycerol, XIX-b) および，セ ラミドホスホリルグリセリンホスフェイト (ceramido phosphoryl glycerolphosphate, XIX-c) の構造を持つ ことが報告され，これら脂質の長鎖塩基としては 17-メ チルオクタデカスフィンガニン (17-methyl octadecasphinganine, XX) が大部分で 63\%を占めている ${ }^{83) 。 ~}$ この菌に見いだされたグリセリンを含むスフィンゴリピ ド（XIX-b，c）は最近まで知られていなかったものであ る。

また, Mycoplasma gallisepticum にスフィンゴミエ リン (sphingomyelin, XXI) が存在し ${ }^{84)}$, Mycoplasma S 743 株 ${ }^{85)}$ には， N-オキシアシル基を持つセラミドグ リセロホスフェイトが含まれているが，括もなホスホス フィンゴリピドは O-アシル基を含むオキシセラミドホ スホリルグリセリン (hydroxyceramide phosphoryl glycerol) であることが報告されている。

\section{4 グリコリピド（糖脂質；Glycolipid）}

バクテリアの大部分の糖脂質は, グリセロ糖脂質とグ 
リセリンおよびスフィンゴシンを含まない糖脂質に区分 される。前者の構造はグリセロリン脂質と似て $s n-1,2-$ ジグリセリドの 3 位に糖がグリコシド結合したグリコシ ルジグリセリドが基本となり, 後者は糖が直接脂肪酸と 結合したアシル化糖（ラムノリピドなど）である。リン 脂質の項で述べたように, バクテリアにはホスホスフィ ンゴリピドはほとんど存在しないが，同様にグリコスフ ィンゴリピドもまた含まれていない。動植物にこれらス フィンゴリピドが存在することと比べ，バクテリア糖脂 質の一つの特徴である。

\section{$4 \cdot 1$ グリコシルジグリセリド（glycosy1 diglyceride)}

これら脂質はリン脂質と同様にクロロホルムーメタ, 一ルで比較的容易に抽出され, 通常, ケイ酸カラムクロマ トグラフィーなどで精製される。バクテリアの代表的な 糖脂質はジグリコシルジグリセリドで，モノ，トリおよ びテトラグリコシルジグリセリドは少量である。 Macfarlane $^{86)}$ によりこのグリコシルジグリセリドとして Micrococcus lysodeikticus から，マンノシルジグリセ リド (mannosyl diglyceride) が初めて分離され, つづ いて Staphylococcus aureus ${ }^{87}$ からグルコシルジグリ セリドが見いだされた。グルコースが 2 分子結合したジ グルコシルジグリセリドが, Polonovski, Wald および Payzant-Diament ら ${ }^{88}$ により，S. aureus から見いだ され，また，トリ拉よびテトラグルコシルジグリセリド が Lactobacillus casei ほか二, 三の菌体より分離され

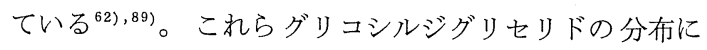
関しては Shaw らの詳しい総説を参照されたい( ${ }^{5), 90) 。 ~}$ これらの脂質はグラム陽性菌に広く分布し ${ }^{90)}$, 光合成菌 とPseudomonas 種の一部を除きグラム除性菌では見い だされていない。先に述べたホスファチジルグリセリン と並びグラム陽性菌脂質の特徵の一つである。

$4 \cdot 1 \cdot 1$ ジグリコシルジグリセリド (diglycosyl diglyceride)

ジグリコシルジグリセリドを構成する糖として，マン ノース，グルコースおよびガラクトースが大部分である が Pseudomonas diminuta ${ }^{63)}$ 打よび Streptomyces LA 7017 $7^{11}$ にグルクロン酸やガラクツロン酸を含むジ グリコシルジグリセリドが見いだされている。この構成 糖および結合様式によりジグリコシルジグリセリドは拉 もに五つの型に分類される。それらの構造をXXII XXVI に示した。

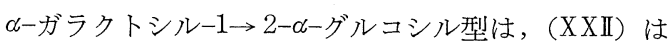
Pneumococcus I, XIV 型菌拉よび Lactobacillus 属の 菌に証明されている。 Streptococcus 属のほかに, Mycoplasma laidlawii に, ß-ジグルコシル型 (XXIV) は Staphylococcus と Bacilliraceae に， coccus lysodeikticus 抢よび Arthrobacteria に, $\beta$-ジ ガラクトシル型 (XXVI) は Arthrobacteria に見いだ されている。この他の型として最近 Chromatium D 株 にマンノシルグルコシルジグリセリドが見いだされてい る22)。ウロン酸を含むグリコリピドおよびグルコシルグ ルクロノシルジグリセリド (XXVII) がグラム陰性菌 Pseudomonas diminuta の細胞壁から分離され ${ }^{63)}$ ，ま た, Streptomyces LA 7017 $7^{91}$ からグルコシルーアシルガ ラクツロノシルジグリセリド (glucosyl-acyl-galacturonosyl diglyceride, XXVIII) が見いだされている。この ように，同じジグリコシルジグリセリドが同じ属や密接 に関連のある菌に存在することが注目される。

このジグリコシルジグリセリドの生合成は，つぎのよ うにUDP-グルコースなどを利用し段階的に糖が 付加 される反応によることが Pneumococcus XIV 型菌で示 され(3),9:1)，他のジグリコシルジグリセリドも同じよう な反応で合成されることが証明されている ${ }^{95) ~ 97) 。 こ の ~}$ 反応は，1,2-ジグリセリドに特異的で，1,3-ジグリセリ ドは利用されない。

$$
\begin{aligned}
& \text { ジグリセリド UDP-グルコース グルコシルジグリセリド } \\
& \text { \UDP-カカラクトース } \\
& \text { ガラクトシルグルコシル } \\
& \text { ジグリセリド }
\end{aligned}
$$

Micrococcus lysodeikticus によるジマンノシルジグ リセリド生合成においては GDP-マンノースからジグ リセリドヘマンノースを転移させる第一段階の酵素反応 と，マンノシルジグリセリドへさらにつぎのマンノース を付加する第二段階の反応で，金属イオンおよび界面活 性剂の要求性が異なることが報告されている ${ }^{95)}$ 。

4.1.2 モノグリコシルジグリセリド（monoglycosyl diglyceride)

ジグリコシルジグリセリドが生合成される際の前駆体 として知られているが，二，三の菌体を除き主構成脂質 ではない。構成糖としてガラクトース,グルコースおよ びグルクロン酸が知られている。Pseudomonas rubescens $^{98}$ に $\beta$ 結合したモノグルコシル拉よびモノグルク ロノシルジグリセリドが, $P$. diminut ${ }^{63)}$ に，また，1-

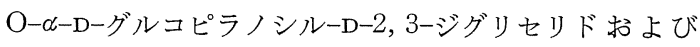

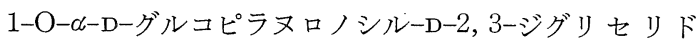
が報告され，このほか，モノガラクトシルジグリセリ ドが, Arthrobacteria globiformis ${ }^{99)}$ や Mycoplasma mycoides $^{100)}$ に存在することが報告されている。 $M$. mycoides では，ガラクトフラノース型で見いだされた 2 番目のものである。グリコシルジグリセリドのこれら 菌体内に扔ける役割について, Shaw ${ }^{5)}$ はいくつかの仮 説をあげており，

a) 多糖類鎖の糖転移の中間体，

b）糖類の貯蔵およびグルコースなどの膜透過の際の 
にない手，および

c）リン脂質とともに，膜構造の維持が考えられる。 今後の研究によりこれら脂質の役割が明らかにされる ことが期待される。

\section{$4 \cdot 2$ アシル化糖}

バクテリアに広く分布し, この種のグリコリピドの代 表的なものとして, Pseudomonas aeruginosa からラ ムノリピドが見いだされている。この構造は Edward, Hayashi ら ${ }^{101)}$ にりり明らかにされた。

このほか, トリアシル化グルコースおよびテトラアシ ル化グルコースが知られており，前者はMycoplasma J 株のおもなグリコリピド ${ }^{102)}$ として，3,4,6-トリアシル$\beta$-Dーグルコピラノース構造をしており, そのアシル基は おもにオレイン酸残基であった。後者はStreptococcus faecalis ${ }^{103)}$, Aerobacter aerogenes および E. coli な どに見いだされ，3,4,6-トリ-O-アセチル-2-O-ラウロ イルグルコピラノースである。最近, propionic acid bacteria 中にジアシルミオイノシットマンノシド81),104) が見いだされ，この構造は，Mycobacteriaceae 科に特 異的に存在するコードファクター，6,6'-ジアシルー2,2'トレハロースの構造に似ている。

\section{5 むす び}

細菌の脂質, とくに, 複合脂質 (リン脂質, 糖脂質) について最近までに得られた成果を紹介したのである が, 要約的にいえることは, 近縁関係にある菌の脂質組 成はおおむね類似していること, および, グラム陰性菌 は共通のリン脂質組成を持つ 4 群に分類できることなど である。これらのことは, 将来, 細菌分類上の有効な手 段となるかも知れない。

細菌から得られる膜標品の脂質組成は動物組織のそれ より比較的簡単であり，また，その膜に変化をもたらす ような条件にも細菌はしばしば耐えらるので，生体膜の 構造および機能に果たしている脂質の役割を研究する上 で, 細菌膜は有効な材料であると思われる。 (昭和 46 年 6 月 16 日受理)

\section{文献}

1) M. Kates, Adv. Lipid Res., 217 (1964)

2) J, Asselineau "Les lipides bactériens", Herman(1962)

3) M. Kates, M.K. Wassef, Ann. Rev. Biochem, 39 323 (1970)

4) M. Ikawa, Bacteriol. Rev., 31, 54 (1967)

5) N. Shaw, Bacteriol. Rev., 34, 365 (1970)

6）赤松 “生化学研究法”, I, p. 168

7) C.L. Randle, P.W. Albro, H.C. Dittmer, Biochim. Biophys. Acta, 187, 214 (1969)

8) U.M.T. Houtsmuller, L.L.M. Van Deenen, Biochem. J., 88, 43 p (1963)

9) M. Kates, D.J. Kushner, A.T. James, Can. J. Biochem. Physiol., 40, 83 (1962)

10) D.B. Sinha, W.L. Gaby, J. Biol. Chem., 239, 3668
(1964)

11) M.D. Yudkin, Biochem. J., 82, 40 p (1962)

12) N.A. Baumann, P.O. Hagen, H. Goldfine, J. Biol. Chem., 240, 1559 (1965)

13) M. Kates, S.N. Sehgal, N.E. Gibbons, Can. J. Microbiol., 7, 427 (1961)

14) R.A. Makula, W.R. Finnerty, J. Bacteriol.; 103, 348 (1970)

15) D. Subrahmanyan, A.N. Nandedkar, R. Viswanathan, Biochim. Biophys. Acta., 63, 542 (1962)

16) M.A. Lanéelle, J. Asselineau, G. Castelnuovo, Ann. Inst. Pasteur, 108, 69 (1965)

17) I. Yano, Y. Furukawa, M. Kusunose, J. Bacteriol., 98, 124 (1969)

18) J. Lascelles, J.F. Szilagyi, J. Gen. Microbiol., 38, 55 (1965)

19) A.A. Benson, J.F.G.M. Wintermans, R. Wiser, Plant. Physiol., 34, 315 (1959)

20) G.E. Jones, A.A. Benson, J. Bacteriol., 89, 260 (1965)

21) H. Goldfine, M.E. Ellis, J. Bacteriol., 87, 8 (1964)

22) T. Kaneshiro, A.G. Marr, J. Lipid Res., 3, 184 (1962)

23) O.W. Thiele, D. Busse, K. Hoffmann, European J. Biochem., 5, 513 (1968)

24) H. Goldfine, P.O. Hagen, J. Bacteriol., 95, 367 (1968)

25) I.J. Sud, D.S. Feingold, J. Bacteriol., 104, 289 (1970)

26) H. Goldfine, Biochim. Biophys. Acta., 59, 504(1962)

27) S.A. Short, O.C. White, M.I.H. Aleen, J. Bacteriol., 99, 142 (1969)

28) D.C. White, A.N. Tucker, J. Lipid Res., 10, 220 (1969)

29) E. Bishara, H.P. Schwarz, Bacteriol. Proc., 120 (1969)

30) P. Plackett, Ann. N.Y. Acad. Sci., 143, 158 (1967)

31) J.M.D.S. Mota, J.A.F. Op Den Kamp, H.M. Verheij, L.L.M. Van Deenen, J. Bacteriol., 104, 611 (1970)

32) M. Kates, P.S. Sastry, L.S. Yengoyan, Biochim. Biophys. Acta., 70, 705 (1963)

33) M. Kates, L.S. Yengoyan, P.S. Sastry, Biochim. Biophys. Acta, 98, 252 (1965)

34) C.L. Marshall, A.D. Brown, Biochem. J., 110, 441 (1968)

35) M. Matsumoto, K. Tamiya, K. Koizumi, J. Biochem., 69, 617 (1971)

36) M.G. Macfarlane, Nature, 196, 136 (1962)

37) U.M.T. Houstmuller, L.L.M. Van Deenen, Biochim. Biophys. Acta, 106, 564 (1965)

38) W.J. Lennarz, P.P.M. Bonsen, L.L.M. Van Deenen, Biochemistry, 6, 2307 (1967)

39) J.G. Molotkovsky, L.D. Bergelson, Chem. Phys. Lipids, 2, 1 (1968)

40) J.A.F. Op Den Kamp, I. Redai, L.L.M. Van Deenen, J. Bacteriol., 99, 298 (1969)

41) D.C. White, F.E.Frerman, J. Bacteriol., 94, 1854 (1967)

42) M. Ikawa, J. Bacteriol., 85, 772 (1963)

43) U.M.T. Houstmuller, L.L.M. Van Deenen, Biochim. Biophys. Acta, 70, 211 (1963)

44) C. Urakami, K. Umetani, Biochim. Biophys. Acta, 164, 64 (1968)

45) J.M. Shively, H.W. Knoche, J. Bacteriol., 98, 829 (1969) 
46) F.J. Kocun, Biochim. Biophys. Acta, 202, 277 (1970)

47) J.E. Kunsman, J. Bacteriol., 103, 104 (1970)

48) D.R. Lang, D.G. Lundgren, J. Bacteriol., 101, 483 (1970)

49) J.A. Nesbitt, W.J. Lennarz, J. Biol. Chem., 243, 3088 (1968)

50) R.M. Gould, M.P. Tharnton, V. Liepkalons, W.J. Lennarz, J. Biol. Chem., 243, 3096 (1968)

51) U.M.T. Houstmuller, L.L.M. Van Deenen, Biochim. Biophys. Acta, 84, 96 (1964)

52) J.A.F. Op Den Kamp, F.W. Van Iterson, L.L.M. Van Deenen, Biochim. Biophys. Acta., 135, 862 (1967)

53) G.K. Khuller, D. Subrahmanyam, J. Bacteriol., 101, 654 (1970)

54) P.F. Smith, C.V. Henrikson, J. Lipid Res., 6, 106 (1965)

55) N. Shaw, P.F. Smith, W.L. Koostra, Biochem. J., 107, 329 (1968)

56) B.P.F. Smith, Bacteriol. Proc., 121 (1969)

57) N. Shaw, P.F. Smith, H.M. Verheij, Biochem. J., 120, 439 (1970)

58) W. Fischer, Biochem. Biophys. Res. Comm., 41, 731 (1970)

59) S.A. Short, D.C. White, J. Bacteriol., 104, 126(1970)

60) W. Fischer, W. Seyferth, Z. Physiol. Chem., 349, 1662 (1968)

61) F.A. Ibbott, A. Abrams, Biochemistry, 3, 2008(1964)

62) I. Ishizuka, T. Yamakawa, J. Biochem, 64, 13(1968)

63) S.G. Wilkinson, Biochim. Biophys. Acta, 187, 492 (1969)

64) J.A.F. Op Den Kamp, P.P.M. Bonsen, L.L.M. Van Deenen, Biochim. Biophys. Acta, 176, 298 (1969)

65) P.J.R. Phizackerley, J.C. MacDougall, M.J.D. Francis, Biochem. J. 99, 21 C (1966)

66) J.A.F. Op Kamp, U.M.T. Housetmuller, L.L.M. Van Deenen, Biochim. Biophys. Acta, 106, 438 (1965)

67) J.A.F. Op Den Kamp, L.L.M. Van Deenen, Chem. Phys. Lipids, 1, 86 (1966)

68) J.C. MacDougall, P.J.R. Phizackerley, Biochem. J., 114, 361 (1969)

69) Y.C. Lee, C.E. Ballou, Biochemistry, 4, 1395 (1965)

70) P. Brennan, C.E. Ballou, J. Biol. Chem., 242, 3046 (1967)

71) M.C. Pangborn, J.A. Mcktnney, J. Lipid Res., 7, 627 (1966)

72) P. Brennan, C.E. Ballou, Biochem. Biophys. Res. Comm., 30, 69 (1968)

73) E. Vilkas, E. Lederer, Bull. Soc. Chim. Biol., 36, 111 (1956)

74) J. Asselineau, Biochim. Biophys. Acta, 54, 359(1961)
75) N.F. Gomes, T. Ioneda, J. Pudless, Nature, 211, 81 (1966)

76) P.J. Brennan, Biochem. J., 109, 158 (1968)

77) C.E. Ballou, E. Vilkas, E. Ledere, J. Biol. Chem., 238, 69 (1963)

78) C.E. Ballou, Y.C. Lee, Biochemistry, 3, 682 (1964)

79) S. Nojima, J, Biochem., 46, 607 (1959)

80) N. Shaw, F. Dinglinger, Biochem. J., 112, 769(1969)

81) V. Rizza, A.N. Tucker, D.C. White, J. Bacteriol., 101, 84 (1970)

82) J.P. LaBach, D.C. White, J. Lipid Res., 10, 528 (1969)

83) D.C. White, A.N. Tucker, C.C. Sweeley, Biochim Biophys. Acta, 187, 527 (1969)

84) M.E. Tourteleotte, R.G. Jensen, G.W. Gander, H.J. Morowitz, J. Bacteriol., 86, 370 (1963)

85) P. Plackertt, P.F. Smith, W.R. Mayberry, J. Bacteriol., 104, 798 (1970)

86) M.G. Macfarlane, Biochem. J., 80, 45 (1961)

87) M.G. Macfarlane, Biochem. J., 82, 40 (1962)

88) J. Polonovski, R. Wald, M.P. Diament, Ann. Inst. Pasteur, 103, 32 (1962)

89) N. Shaw, K. Heatherington, J. Baddiley, Biochem. J., 107, 491 (1968)

90) N. Shaw, J. Baddiley, Nature, 217, 142 (1968)

91) L.D. Bergelson, S.G. Batrakov, T.V. Pilipenko, Chem. Phys. Lipids, 4, 181 (1970)

92) S. Steiner, S.F. Conti, R.L. Lester, J. Bacteriol., 98, 10 (1969)

93) J. Distler, S. Roseman, Proc. Nat. Acad. Sci. U.S.A., 51, 897 (1964)

94) B. Kaufmann, F.D. Kundig, J. Distler, S. Roseman, Biochem. Biophys. Res. Comm., 18, 312 (1965)

95) W.J. Lennarz, B. Talamo, J. Biol. Chem., 241, 2207 (1966)

96) R.A. Pieringer, J. Biol. Chem., 243, 4894 (1968)

97) P.F. Smith, J. Bacteriol., 99, 480 (1969)

98) S.G. Wilkinson, Biochim. Biophys. Acta, 164, 148 (1968)

99) R.W. Walker, C.P. Bastl, Carbohyd. Res., 4, 49 (1967)

100) P. Plackett, Biochemistry, 6, 2746 (1967)

101) J.R. Edwards, J.A. Hayashi, Arch. Biochem. Biophys., 111, 415 (1965)

102) P.F. Smith, W.R. Mayberry, Biochemistry, 7, 2706 (1968)

103) K. Welsh, N. Shaw, J. Baddiley, Biochem. J., 107, 313 (1968)

104) C. Prottey, C.E. Ballou, J. Biol. Chem., 243, 6196 (1968)

105) Y. Kamio, S. Kanegasaki, H. Takahashi, J. Gen. Appl. Microl., 15, 439 (1969) 